OPEN ACCESS

Edited by:

Adeyemi Oludapo Olusola,

University of Ibadan, Nigeria

Reviewed by:

Henry Bikwibili Tantoh,

The University of

Bamenda, Cameroon

Temitope Oluwaseun Ojo,

Obafemi Awolowo University, Nigeria

*Correspondence:

Israel R. Orimoloye

orimoloyeisrae/@gmail.com

orcid.org/0000-0001-5058-2799

Specialty section:

This article was submitted to

Urban Agriculture,

a section of the journal

Frontiers in Sustainable Food Systems

Received: 29 November 2021 Accepted: 22 December 2021

Published: 01 February 2022

Citation:

Orimoloye IR (2022) Water, Energy and Food Nexus: Policy Relevance

and Challenges.

Front. Sustain. Food Syst. 5:824322.

doi: 10.3389/fsufs. 2021.824322

\section{Water, Energy and Food Nexus: Policy Relevance and Challenges}

\author{
Israel R. Orimoloye ${ }^{1,2 *}$ \\ ${ }^{1}$ Centre for Environmental Management, University of the Free State, Bloemfontein, South Africa, ${ }^{2}$ Department of Geography \\ and Environmental Science, University of Fort Hare, Alice, South Africa
}

Connections between water, food, and energy are at the center of long-term economic and environmental development and protection. Water, energy and food are the keys to economic input and a necessary component of economic progress. The adoption of water management policies and techniques that support the sustainable use of resources while promoting economic growth is becoming an important concern, particularly in countries where water and food scarcity are critical or problematic. This study aimed at evaluating Water, Energy and Food Nexus (WEF), and as well as challenges of its implementation. This study looked at the articles that were published on WEF nexus between 2015 and 2021 acquired from the Scopus database, focusing on gaps and implementations. I searched for relevant key terms in the database and the search found hundreds of articles on WEF, of which 28 articles were relevant to the scope of the study and these articles were downloaded as BibTeX file for the analysis and the analysis was done using $R$ programming. A number of insights and implications were identified based on the analyses of the findings of the reviewed research in order to increase the policy relevance and overall implementation of the WEF nexus by public policy and decision-making institutions. To boost uptake of the findings, the study gives an outline of the primary constraints and challenges that restrict the policy relevance of the WEF nexus.

Keywords: water, energy, food, WEF nexus, implementation, challenges

\section{INTRODUCTION}

Water, Energy and Food Nexus (WEF) or the linkages between the water, energy, and food (WEF) sectors, is becoming a major academic, policy, and sociological topic that is increasingly debated in a global society, including the relationship with ecosystems, livelihoods, and the economy (Hülsmann et al., 2019; Purwanto et al., 2021). The issues of managing water, energy, and food resources at the same time while meeting several possibly conflicting objectives without jeopardizing any sector's resource-base are important and must be addressed as soon as feasible (i.e., causing the least amount of damage to other sectors). This problem necessitates a holistic strategy in which all systems are evaluated. To add to the complexity, other sectors such as economic, social, political, and environmental factors, as well as effective implementation, influence and are influenced by the WEF nexus (Bizikova et al., 2013; Nhamo et al., 2020; Rosales-Asensio et al., 2020). At the Bonn 2011 nexus Conference, the basic concept of the WEF security nexus strategy was created and widely discussed. The nexus method is characterized as a strategy that integrates management and governance across sectors and scales (Saidmamatov et al., 2020). To address policy difficulties, the confluence of academic ideas and actual execution is critical. 
Initial guidance on how a nexus approach might improve the security of WEF resources by enhancing efficiency, minimizing trade-offs, developing synergies, and improving governance across sectors, as well as various policy proposals, was introduced in Hoff's study (Hoff, 2011). However, extensive investigations and critical evaluations by Endo et al. (2017) and Albrecht et al. (2018) claim that Hoff's background study and the 2011 World Economic Forum meeting (WEF, 2011) have propelled the WEF nexus to the forefront of global attention. Consequently, significant inadequacies in nexus approach frameworks and subsequent nexus studies have been found.

The WEF nexus is defined as the mutual interconnections between water, energy and food. The WEF nexus is critical to natural resource management and climate change policy because societal changes drive WEF demand increases, and continuous environmental changes are likely to impact water supply or accessibility (Mpandeli et al., 2018; Orimoloye et al., 2018; Busayo et al., 2019; Bakhshianlamouki et al., 2020; Dyosi et al., 2021). To deal with the WEF nexus, multi-sectoral water use must be harmonized and brought into line with water (basin) integrity reconstruction and/or preservation. The WEF nexus, in contrast to integrated water resources management (IWRM), emphasizes non-linear system analysis and dynamic feedbacks across waterintensive industries. The piece of knowledge relating to water in the WEF nexus has grown significantly during the last decade (Hack, 2015; Al-Saidi, 2017).

Several concepts, theories, and methodologies have been done using a nexus approach to look at the links between water, energy, and food (Mohtar and Daher, 2012; El-Gafy, 2017; Bizikova, 2019). Study has provided a thorough analysis of the WEF nexus, including basic linkages as well as institutional and policy implementation difficulties and enhancing adaptive capacity to complex global challenges (Scott et al., 2015; Busayo et al., 2019). In support of food security, sustainable agriculture, and human development, the United Nations Food and Agriculture Organization (FAO., 2014) offered a conceptual approach to the WEF nexus, balancing diverse user purposes and interests. In the nexus approach, the environmental effect has been analyzed while evaluating the relationships and balance between water, energy, land, and food, as well as the importance of wellbeing (Ringler et al., 2013; Orimoloye et al., 2019).

In an effort to examine the green economic growth potential of a nexus approach, Hoff (2011) presents preliminary evidence on how a nexus approach might boost water, energy, and food security by increasing efficiency, eliminating trade-offs, developing synergies, and improving governance across sectors (Tantoh et al., 2020). With this knowledge gap especially on WEF nexus implementation and policy relevance, it is critical to include relevant studies outcomes in the decision-making processes, this will help in effectively implementing WEF nexus. The role of scientific research in bridging the nexus knowledge gap, quantifying nexus critical interlinkages and interactions, and identifying trade-offs and possible synergies to support evidence-based policymaking is very important, especially in developing countries (Wichelns, 2017; Tantoh et al., 2021). Consequently, this study aimed at evaluating studied on WEF nexus and how this nexus has been implemented over the years as well as identifying the potential barriers to its implementation. The issues of managing and implementing water, energy, and food resources policy and meeting several possibly conflicting objectives without jeopardizing any sector's resource-base are important and must be addressed scientifically this will help in causing the least amount of damage to other sectors. This problem necessitates a holistic strategy in which all systems are evaluated.

\section{METHODOLOGY}

This study looked at the academic articles that were published on WEF nexus between 2015 and 2021, focusing on gaps and implementations. The first step was to go over the existing WEF nexus studies and see where they have been improved or failed to be implemented, as well as critical areas that were left out of most, if not all, of them. The second stage was to identify numerous important phrases that appear in WEF nexus studies in order to identify the knowledge, research, and application gaps. These procedures enable the most pressing concerns in current nexus research to be identified. Following that, several WEF nexus case studies were evaluated, demonstrating the extent to which WEF nexus approach practices and impediments to adoption exist. Figure 1 depicts the steps taken in this research. The framework of this study reflects these steps.

Primarily, the search term was WEF nexus and it was refined by excluding other irrelevant studies and document types: (article) timespan: all years' indexes: SCI-expanded, SSCI, A\&HCI, CPCI-S, CPCI-SSH, BKCI-S, BKCI-SSH, ESCI, CCREXPANDED, IC. The title-specific algorithm only retrieved primary articles and excluded other document types for the primary reasons that they were pre-article items that could be published in other forms or post-publication synthesis of primary articles. Manual validation of the total articles was further done to ascertain the specificity and efficiency of the search algorithm in recovering the subject keyword from the database (Orimoloye and Ololade, 2021). On overall, the dataset contained 28 relevant articles and was downloaded as BibTeX file.

The existing WEF nexus implementation was selected in this study based on studies published in an academic database such as Scopus databases. The databases were used to identify peerreviewed scientific documents and other publications that used the WEF nexus concept during the period 2015-2021. Further investigation was conducted to clarify the main concerns, key terms frequently used words and variables of the studies. While not meant as comprehensive, the results are representative of the commonly presented WEF nexus available in the literature, and many gaps and barriers were identified in this study. The information on the articles on WEF nexus used in this study is presented in Table 1. The annual Growth Rate of research studies published during the period of study per year is $24.57 \%$, while the annual average citations as presented in Table 1, is 17.36. different authors and researchers were involved in these studies, for instance, total authors of about 115 with author appearances of 127 were recorded in the studies used in the study. 


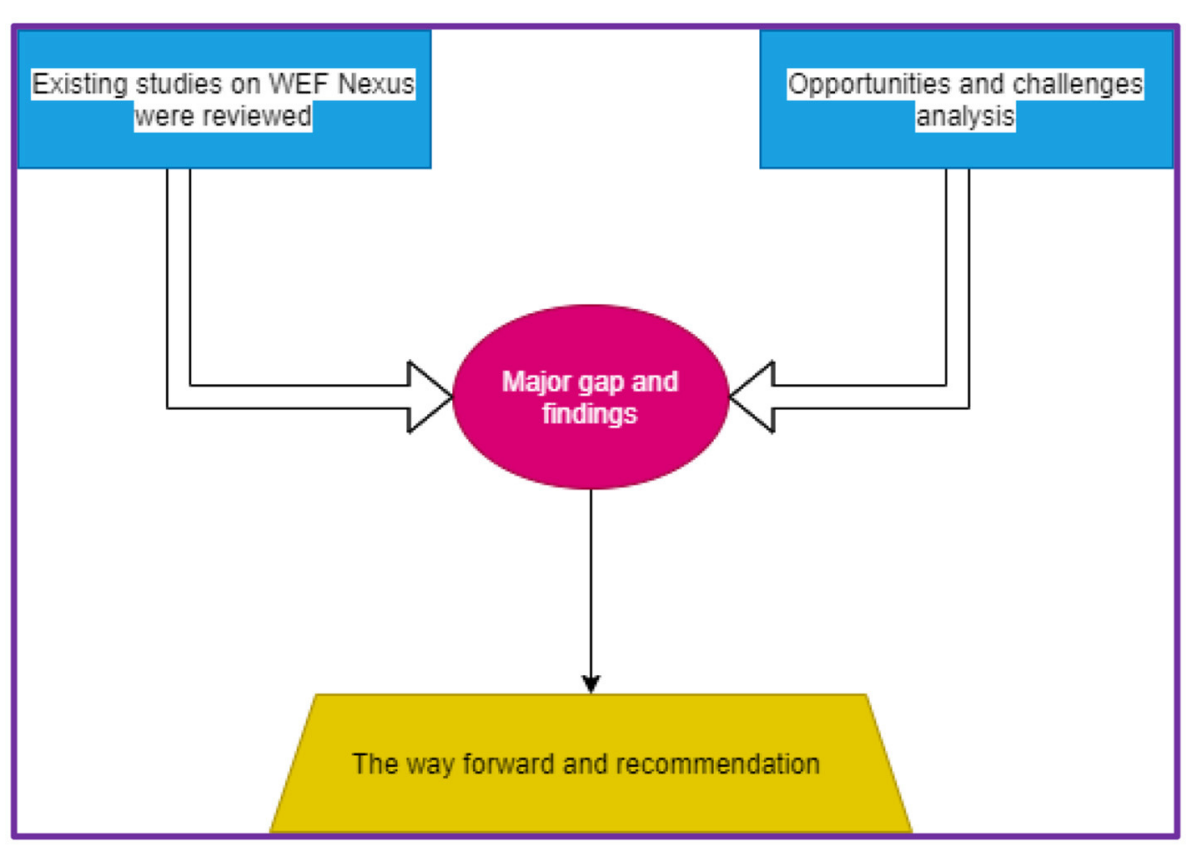

FIGURE 1 | Schematic flow chart of the process.

\section{RESULTS AND DISCUSSION \\ Practices and Barriers to Implementing WEF Nexus Approach}

The WEF nexus has the potential to provide new opportunities in any region where the nexus is well-implemented in general. However, there is also concern that these opportunities created in the medium term will only be for a small number of talented individuals, experts, causing opportunities in other competitive areas (e.g., agriculture and energy sectors). A significant barrier to the technical implementation of the WEF nexus is the absence of precise and uniform data for the whole world. No specific organization providing WEF nexus information to set up a uniform database and provide links to water-related initiatives, papers, events, etc., requires greater contributions from various regions of the world especially in developing countries. Several countries have only low levels of data availability and accuracy, while detailed socio-economic and climate data are necessary to conduct a regional and inter-regional WEF nexus analysis. Furthermore, some countries may be unwilling to share certain types of required data, as they could be considered nationally strategic (Markantonis et al., 2019).

In terms of potential WEF trade-offs, since product systems are so intertwined, measures taken at the local level to improve one aspect of the WEF nexus may cause burdens to be shifted to other areas, resulting in negative consequences for water, energy, or food security. To avoid this, when evaluating different policy options, a lifecycle perspective should be used. Industry, for example, uses lifecycle methodologies and procedures to address water risks. Water security impacts extend beyond manufacturing sites throughout the entire supply
TABLE 1 | Information on the articles on WEF nexus used in this study.

\begin{tabular}{|c|c|}
\hline Description & Results \\
\hline Documents & 28 \\
\hline Sources (Journals, Books, etc.) & 18 \\
\hline Keywords Plus (ID) & 212 \\
\hline Author's Keywords (DE) & 119 \\
\hline Period & 2015-2021 \\
\hline Average citations per documents & 17,36 \\
\hline Authors & 115 \\
\hline Author Appearances & 127 \\
\hline Authors of single-authored documents & 3 \\
\hline Authors of multi-authored documents & 112 \\
\hline Single-authored documents & 3 \\
\hline Documents per Author & 0,243 \\
\hline Authors per Document & 4,11 \\
\hline Co-Authors per Documents & 4,54 \\
\hline Collaboration Index & 4,48 \\
\hline \multicolumn{2}{|l|}{ Document Types } \\
\hline Article & 17 \\
\hline Book Chapter & 4 \\
\hline Conference Paper & 1 \\
\hline Editorial & 1 \\
\hline Review & 5 \\
\hline
\end{tabular}

chain, particularly in the case of agricultural products, which frequently require considerable amounts of water and energy for management and harvesting. The virtual water content of traded products could be a useful indicator for assessing supply 
TABLE 2 | Challenges and gaps in the WEF concept.

\begin{tabular}{|c|c|c|c|}
\hline & $\begin{array}{l}\text { Main Challenges and } \\
\text { gaps }\end{array}$ & Description & References \\
\hline 1 & $\begin{array}{l}\text { The combined } \\
\text { components in the } \\
\text { nexus are too broaden }\end{array}$ & $\begin{array}{l}\text { The Water-Energy-Food (WEF) nexus is currently being promoted and } \\
\text { developed in response to this challenge, providing a tool to improve these } \\
\text { elements through an interdisciplinary approach that recognizes the inherent } \\
\text { synergies and trade-offs involved in the management of these components }\end{array}$ & $\begin{array}{l}\text { Fernández-Ríos et al. (2021) and } \\
\text { Proctor et al. (2021) }\end{array}$ \\
\hline 2 & $\begin{array}{l}\text { Different regions face } \\
\text { different issues among } \\
\text { the three components in } \\
\text { the WEF nexus }\end{array}$ & $\begin{array}{l}\text { Water, energy and food issues, sometimes all three components may not be } \\
\text { problematic as one may not be impacted. Some countries, particularly } \\
\text { those in underdeveloped countries, have faced security issues as a result of } \\
\text { the WEF. Water security is a hotspot issue in WEF security, with just around } \\
3 \% \text { of the world's estimated } 1.4 \text { billion } \mathrm{km}^{3} \text { of water available for } \\
\text { consumption. The Middle East is dealing with both water and food security } \\
\text { issues at the same time but not necessarily energy. Furthermore, more } \\
\text { problematic locations such as North Africa and West Asia must deal with } \\
\text { water, energy, and food security issues. }\end{array}$ & $\begin{array}{l}\text { Fedoroff et al. (2010), Antonelli } \\
\text { and Tamea (2015), King and } \\
\text { Jaafar (2015), Yillia (2016) and } \\
\text { Hua et al. (2021) }\end{array}$ \\
\hline 3 & $\begin{array}{l}\text { Interdisciplinary } \\
\text { concepts of WEF nexus }\end{array}$ & $\begin{array}{l}\text { The nexus welcomes multidisciplinary dialogue between complex system } \\
\text { methodologies capable of quantifying resource relationships and policy } \\
\text { analysis addressing coherence and integration tools as an analytical notion. } \\
\text { On a practical level, the nexus necessitates transdisciplinary collaboration } \\
\text { with people concerned with water, food, and energy management. In this } \\
\text { context, gaps in social-science-driven multidisciplinary nexus assessments } \\
\text { and how multiple knowledge systems might be braided into nexus research } \\
\text { and can be problematic in terms of different perspectives. }\end{array}$ & $\begin{array}{l}\text { Mohtar and Daher (2012), } \\
\text { Albrecht et al. (2018), Hoolohan } \\
\text { et al. (2018), Venghaus and Hake } \\
\text { (2018), Zhang et al. (2018) and } \\
\text { Cabello et al. (2021) }\end{array}$ \\
\hline 4 & $\begin{array}{l}\text { Climate change and the } \\
\text { increasing complexity of } \\
\text { modern WEF }\end{array}$ & $\begin{array}{l}\text { WEF nexus is challenged by climate change and the increasing complexity } \\
\text { of modern WEF relationships, some systems and irrigation schemes have } \\
\text { survived for millennia and still exist in recognizable form. This is due in large } \\
\text { part to the persistence of governance systems that devolved significant } \\
\text { decision-making authority to those who used water and energy for food } \\
\text { production. }\end{array}$ & Pueppke (2021) \\
\hline 5 & Normative & $\begin{array}{l}\text { The current debate over the WEF nexus principle raises many questions, } \\
\text { including the depth to which such conceptualizations are truly new, whether } \\
\text { they substitute (or complement) existing environmental governance } \\
\text { approaches, and how the nexus can be strengthened in national contexts if } \\
\text { it is considered normatively desirable. }\end{array}$ & Purwanto et al. (2021) \\
\hline 6 & $\begin{array}{l}\text { WEF nexus does not } \\
\text { usurp integrated water } \\
\text { resources management } \\
\text { (IWRM) models }\end{array}$ & $\begin{array}{l}\text { It has been identified that the integration between water, energy, climate and } \\
\text { agricultural policy objectives is still generally limited, even with the existence } \\
\text { of the WEF nexus. }\end{array}$ & Purwanto et al. (2021) \\
\hline 7 & Applicability & Low-level applications by the supposed to be users such as farmers, fishers. & Endo et al. (2017) \\
\hline 8 & $\begin{array}{l}\text { It is mostly a narrative } \\
\text { concept }\end{array}$ & $\begin{array}{l}\text { In most cases, the WEF nexus concept resulted in unforeseen changes in } \\
\text { issues based on context, place, and size, with no way to fix the issues. }\end{array}$ & Bell et al. (2016) \\
\hline 9 & Culture and politics & $\begin{array}{l}\text { The implementation of WEF nexus policies in some regions especially in } \\
\text { developing nations may be hampered by cultural and political issues. Due to } \\
\text { the complex political situation and socio-cultural traditions, it is unclear how } \\
\text { communities would react to the implementation of WEF nexus policies. } \\
\text { Interest in integrated resource management could be sparked by } \\
\text { participatory initiatives, increased awareness, and capacity building. }\end{array}$ & Mabhaudhi et al. (2018) \\
\hline 10 & $\begin{array}{l}\text { Poor education, } \\
\text { urbanization, and } \\
\text { poverty }\end{array}$ & $\begin{array}{l}\text { The WEF nexus may encounter several challenges that could hinder the } \\
\text { effective implementation of its associated policies and guidelines. Inequality } \\
\text { remains an issue, particularly in terms of access to quality education and } \\
\text { resources. }\end{array}$ & Mabhaudhi et al. (2018) \\
\hline
\end{tabular}

chain trade-offs. The lack of lifecycle-based data to supplement local databases in various regions is a critical issue (Table 2) that would require significant improvement in national accounting. Issues with water, energy, and food are sometimes not critical in some places since only one of the three components is affected. As a result of the WEF, certain countries, particularly those in developing countries, have had security difficulties. Some of these activities or issues may not be applicable to or adopted by all countries; however, this does not negate their importance as food for thought.

\section{WEF Nexus Opportunities: A Review of Current Approaches and Policies}

A number of insights and implications have been identified based on the analyses of the findings of the reviewed research in order to increase the policy relevance and overall implementation of the 


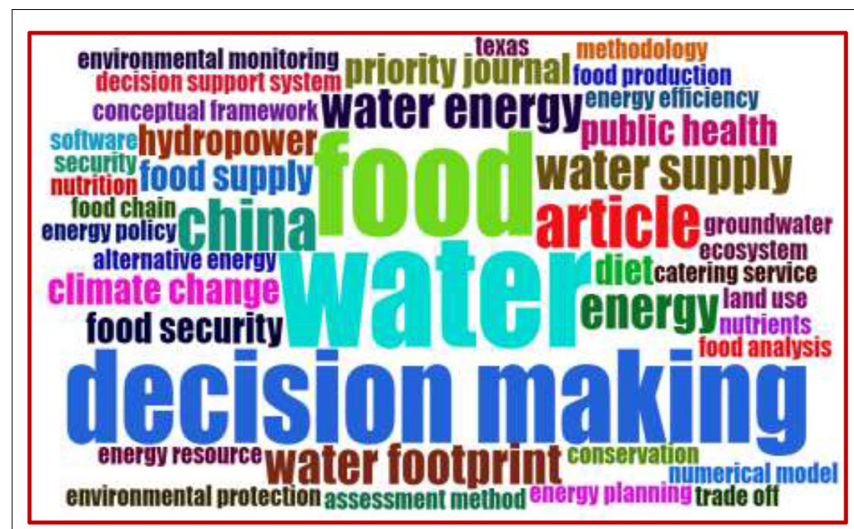

FIGURE 2 | Wordcloud

WEF nexus by public policy and decision-making institutions. To boost uptake of the findings, the study identified various challenges in facilitating effective implementation of the WEF nexus as well as the acceptability between researchers and policymakers. This study also gives an outline of the primary constraints and challenges that restrict the policy-relevance of the WEF nexus analyses in this study.

The information in Figure 2 summarized the evolution of WEF nexus-related research used in the studies examined in this study in a wordcloud. Wordcloud was used on the titles of the published papers selected based on the search words. It indicates the predominant word or term used in the WEF coupled with its potential implementation studies. It is easy to distinguish and figure out different areas of associations and prominent terms within the wordcloud (Afuye et al., 2021a; Orimoloye et al., 2021a). This was done to know the research trends in the WEF nexus research field and to identify the most emerging and frequent keywords used in the field. For instance, the relevant words or frequently mentioned words in the WEF nexus studies are water, food, decision making, sustainable development which were mentioned $11,10,9$, and 7 times respectively in the author's key terms used in WEF nexus studies (Figure 2). These connote that all these prominent themes are relevant in WEF nexus studies.

The information in Figure 3 depicts the word dynamics of WEF nexus studies. Word dynamics analysis is a tool for classifying things that focuses on existent (rather than calculated, such as through profiles) linkages between them, such as in WEF nexus investigations. In WEF nexus research, a scientific article merges numerous existing networks, such as themes or word conetworks, into a new original network (based on objects). The word dynamics were produced using the top 10 most often used words (Figure 3). In order to analyze word dynamics, frequent words were also extracted each year. The function "mk.test" in the package "word dynamics" was used to execute trend analysis (growing or decreasing over the last few years), with the significance level of the Mann Kendall test set at 0.05 (Liu et al., 2019; Afuye et al., 2021b). In year 2018, water, food, sustainable development, energy and water supply was mentioned 3, 3, 3, 1, and 2 respectively (Table 3 ).

\section{Identified WEF Nexus Approach Practices and Barriers to Its Implementation}

In economic terms, water is considered a common good with no substitutes. The equitable distribution of this natural resource is controlled by social fairness and efficient allocation (Markantonis et al., 2019). Through trade-offs and an understanding of the multiple stakes involved, the Nexus can provide ways forward in some specific regions where freshwater supplies are limited and need to be allocated efficiently to feed the industrial, residential, agricultural and energy sectors. Individually addressing productive sectors and related natural resources results in high opportunity costs across a variety of uses, as well as higher transaction costs between nexus sectors. As a result, minimizing high transaction costs should be at the forefront of any economic measures considered when adopting (or designing) a WEF nexus approach. Furthermore, water and energy distribution are monopolies with highly regulated externalities that produce both positive and negative externalities. Water provision may have positive externalities in terms of public health benefits, but energy and food production may have negative externalities (point and diffuse pollution). Water pricing should encompass social, environmental, and cultural aspects which are difficult to assess or put into monetary terms when it comes to water management. Water services are heavily subsidized in most parts of the world, particularly in developing countries, and water rates mostly reflect investment and maintenance expenses rather than the resource's potential cost or scarcity. Although water pricing is an important tool, it is insufficient due to the inelastic nature of water demand (raising prices would not significantly reduce usage) and the necessity for sufficient subsidies to help consumers and farmers minimize their expenditures.

The WEF nexus operationalization constraints must be overcome if the WEF nexus sustainability targets are to be met. Complex collaboration between interconnected sectors, diverse sectoral institutional frameworks and interests, insufficient governance frameworks, and a lack of incentive to collaborate with multiple stakeholders from many disciplines and government levels are all challenges that must be overcome (Urbinatti et al., 2020). Uncertainty and anxiety, which are brought on by the fear of the unknown as a result of changing from the usual to creative ways of doing things, are other challenges to WEF nexus implementation.

The WEF nexus has the potential to create new job opportunities particularly in water-stressed regions in general. However, there are some concerns that the new opportunities created in the medium term will only be for a small number of skilled workers, causing unemployment in other competitive sectors (e.g., agriculture) (Markantonis et al., 2019; Nhamo et al., 2020). The lack of exact and uniform data for the entire world on WEF is a key hurdle to the technical implementation of the WEF nexus. The European Environment Agency (EEA) provided the Shared Environmental Information System (SEIS) to set up a 


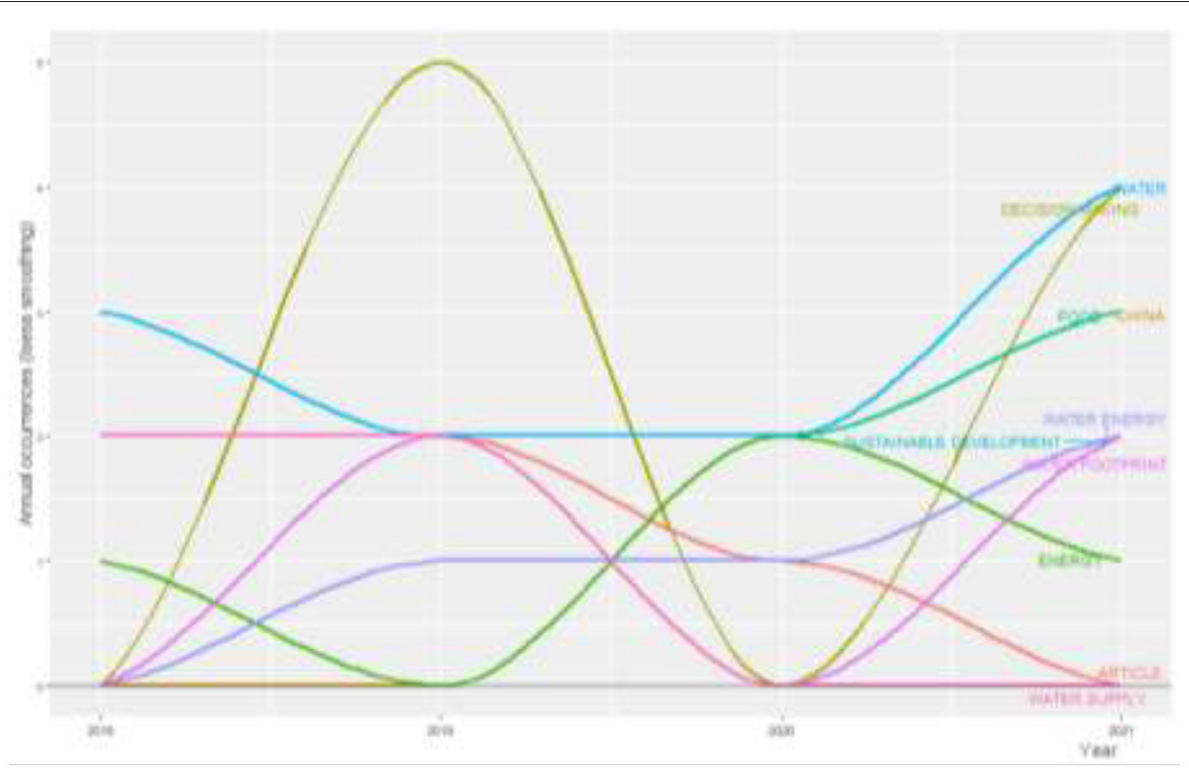

FIGURE 3 | Word dynamics.

TABLE 3 | Frequent key words plus in WEF nexus.

\begin{tabular}{|c|c|c|c|c|c|c|c|c|}
\hline Year & Water & Food & Decision making & Sustainable development & Energy & Water energy & Water footprint & Water supply \\
\hline 2018 & 3 & 3 & 0 & 3 & 1 & 0 & 0 & 2 \\
\hline 2019 & 2 & 2 & 5 & 2 & 0 & 1 & 2 & 2 \\
\hline 2020 & 2 & 2 & 0 & 0 & 2 & 1 & 0 & 0 \\
\hline 2021 & 4 & 3 & 4 & 2 & 1 & 2 & 2 & 0 \\
\hline
\end{tabular}

uniform database and provide links to water-related initiatives, papers, events, and so on (Markantonis et al., 2019). These systems require more contributions from countries especially, developing nations. Several nations have poor data availability and accuracy, despite the fact that precise socioeconomic and climate data are required to undertake a WEF nexus study on a sectoral and intersectoral scale (Boluwade, 2021). Furthermore, some countries may be hesitant to release particular sorts of essential data since they may be regarded as strategically important to their countries.

Limited arable and land water resources are among some of the barriers to the implementation of WEF nexus. Several measures, such as the installation of greenhouses and the use of tankers to transport water to the greenhouses, have been made to address the challenges connected with limited arable and land water resources (Adedeji et al., 2020; Adetoro et al., 2020; Orimoloye et al., 2021b). Natural phenomena such as excessive rainfall caused by cyclones and other climatic events, however, pose many obstacles to the long-term viability of these programs (Martinez et al., 2018; Boluwade, 2021). Due to a lack of a relevant database, the effects of these extreme events produced by climate change on the WEF nexus are not fully known. To the best of our knowledge, few if any research has attempted to give quantitative indicators or metrics from the perspective of climate change's effects on the WEF nexus.

In terms of potential WEF trade-offs, because product systems are so intertwined, measures taken at the local level to improve one aspect of the WEF nexus may cause burdens to be shifted to other areas, resulting in a negative consequence for water, energy, or food security. To avoid this, when evaluating different policy options, a lifecycle perspective may be used. Industry, for example, employs lifecycle methodologies and procedures to address water risks. Water security impacts extend beyond manufacturing sites throughout the entire supply chain, particularly in the case of agricultural products, which frequently require considerable amounts of water and energy for management and harvesting (Ozdogan et al., 2017; Zhao et al., 2018). The virtual water content of traded products could be a useful indicator for assessing supply chain trade-offs. The lack of lifecycle-based data to supplement local databases in the waterscarce region is a difficult problem that would require significant improvements in national accounting systems. The other aspects of the WEF nexus are subject to similar considerations. In terms of energy, for example, activities such as manufacturing processes and product transportation contribute significantly to the whole system's energy and carbon footprints. The lack 
TABLE 4 | WEF nexus implementation.

\begin{tabular}{|c|c|c|c|}
\hline SN & Country/Region & Practices & References \\
\hline 2 & Portugal & $\begin{array}{l}\text { WEF nexus index: Portugal has a value of } 70.2 \text { for the Water pillar, } \\
51.1 \text { for the Energy pillar and } 72.4 \text { for the Food pillar. }\end{array}$ & https://wefnexusindex.org/PRT \\
\hline 2 & Netherlands & $\begin{array}{l}\text { Green Deals Netherlands: Green Deals ideally serve as an } \\
\text { inspiration to others and pave the way for future efforts. Green } \\
\text { Deals ensure broad follow-up and impact on Dutch society, } \\
\text { energy, food, water, resources, biodiversity, mobility, bio-based } \\
\text { economy, climate, and construction are the main issues. }\end{array}$ & $\begin{array}{l}\text { Marchand et al. (2015); } \\
\text { https://www.greendeals.nl/ } \\
\text { english }\end{array}$ \\
\hline 3 & European Union & $\begin{array}{l}\text { Because decarbonisation relies on water-demanding energy } \\
\text { technologies like biofuels, carbon capture, and nuclear power, the } \\
\text { EU has aggressive decarbonisation goals for the future, which } \\
\text { could be impossible to meet if the European water system } \\
\text { becomes too stressed. }\end{array}$ & European Commission (2019) \\
\hline 4 & Italy & $\begin{array}{l}\text { Waste regulation: The Italian legislation imposes very strict limits to } \\
\text { the use of waste water in irrigation. }\end{array}$ & Markantonis et al. (2019) \\
\hline 5 & South Africa & $\begin{array}{l}\text { Irrigation: South Africa aims to increase the area under irrigation by } \\
149000 \text { ha in order to ensure food security. However, there is a } \\
\text { disjoint in this process as they failed to considered the impacts on } \\
\text { water and energy by analyzing all possibilities through the WEF } \\
\text { nexus analytical framework. before implementing such initiatives }\end{array}$ & $\begin{array}{l}\text { National Planning Commission. } \\
\text { (2013) }\end{array}$ \\
\hline
\end{tabular}

of engagement and trust in various stakeholders, particularly civil society, impedes the development of a nexus approach that requires a high level of cooperation and mutual trust. The responsibility for the water, food, and energy is frequently delegated to various ministries or agencies, obstructing the close contact and cooperation required to address the WEF nexus (Markantonis et al., 2019). Innovative partnerships (such as Plan Blue) must be improved at the regional or national level, while this may be difficult given the region's geographical, political, and social contrasts. Through the WEF nexus, science and policy should collaborate to initiate and promote sound planning of solutions for tackling difficulties. However, science and policy have historically had a poor level of cooperation, as they typically have opposing aims, agendas, and priorities. There is also significant doubt about governments' roles, as they do not appear to be ready or equipped to establish a WEF nexus strategy (Oludare et al., 2020). In such circumstances, innovative research may be able to assist in the advancement of the nexus discourse, with national governments responding in accordance with their interest and readiness.

In addition, the WEF nexus would necessitate tight collaboration with the private or commercial sector. The private sector possesses an in-depth understanding of manufacturing processes, management, and the marketplaces in which they operate. People who work in the private sector use natural resources or are in the business of producing or processing them, hence they must be included in the WEF nexus discussion (Lazaro et al., 2021; Naidoo et al., 2021). Because businesses rely on resources such as water, it is also in their financial interest to get involved. They can also give equipment and employees, as well as contribute to nexus solution research and development financing (Naidoo et al., 2021). Many businesses recognize the need to innovate in order to maintain long-term growth, but they are sluggish to establish the necessary links with other stakeholders, such as the public sector and research organizations. Many obstacles can be recognized, such as a lack of communication, a lack of mutual understanding, or variations in the dynamics of the various sectors. To begin a productive dialogue on how the various interests might be matched into a project or program that can simultaneously boost the entrepreneur's business model while also helping to greatly lessen the WEF nexus difficulty (Markantonis et al., 2019; Barbarà Mir, 2020), extra effort is required to overcome these barriers. The circumstances, constraints, and opportunities for the private sector's effective engagement in promoting the nexus should be examined, and strategies for moving forward should be proposed.

\section{Implementation and Practices}

In different countries, different approaches and legislation can be found (Table 4). The use of wastewater in irrigation in Italy is strictly regulated by Italian law (Markantonis et al., 2019). This makes such use extremely difficult because the prices of treatments are too high for farmers to afford. As a result, wastewater is discharged into the sea without being utilized, and wastewater is unlawfully used by farmers without being monitored. Research can help us better understand the most appropriate limitations to be adhered to, the sorts of irrigation systems that can be employed, and the types of crops that can be irrigated with wastewater without causing any health issues for the general public (Hua et al., 2021). Overall, the study's findings could help policymakers make better decisions. The link between water, energy, food security and other sectors can contribute immensely to investments, job development, innovation, and competitiveness. It can be acknowledged that some of these techniques may not be appropriate to or chosen by some countries; nonetheless, this does not negate their significance as something that should be seriously considered (Hua et al., 
2021). The information in Table 4 these activities and the regions where they were implemented. The difficulties of setting and implementing different prices for different sectors that use the same resources; a lack of collaboration between science, policy, and business; a lack of coherence and cooperation between various levels of government; a limited number of success stories and guidelines to help promote innovative partnerships; and a lack of public awareness and support for innovation on WEF nexus needs to be improved.

It is vital to identify the nexus economic and environmental sectors that can benefit from a shift in the planning process in order to go from concepts to implementation. This is a vital element that is missing from the literature. This will aid in identifying regions with developmental constraints, water availability or levels, uneven water allocations by different sectoral water consumers, and areas where food and energy demand is likely to rise in the next decades. The findings or results could help the region achieve long-term economic growth and environmental restoration, among other objectives.

\section{CONCLUSION}

While there is evidence that the water, energy, food nexus approach adds value to sustainable development and is generating interest, if not demand, from a number of countries and institutions, the most important step to take right now is to analyze and debate the related conditions, bottlenecks, opportunities, and paths forward through structured dialogues that lead to action. The main focus of this study is to evaluate studied on water, energy, food nexus and how the nexus has been implemented over the years as well as identifying the potential barriers to its implementation. In this study, challenges and gaps and implementation of water, energy, food nexus were examined most importantly from the perspective of water, energy and food,

\section{REFERENCES}

Adedeji, O., Olusola, A., James, G., Shaba, H. A., Orimoloye, I. R., Singh, S. K., et al. (2020). Early warning systems development for agricultural drought assessment in Nigeria. Environ. Monitor. Assess. 192, 1-21. doi: 10.1007/s10661-020-08730-3

Adetoro, A. A., Abraham, S., Paraskevopoulos, A. L., Owusu-Sekyere, E., Jordaan, H., and Orimoloye, I. R. (2020). Alleviating water shortages by decreasing water footprint in sugarcane production: the impacts of different soil mulching and irrigation systems in South Africa. Groundwater Sustain. Dev. 11:100464. doi: 10.1016/j.gsd.2020.100464

Afuye, G. A., Kalumba, A. M., Busayo, E. T., and Orimoloye, I. R. (2021b). A bibliometric review of vegetation response to climate change. Environ. Sci. Pollut. Res. 1-13. doi: 10.1007/s11356-021-16319-7

Afuye, G. A., Kalumba, A. M., and Orimoloye, I. R. (2021a). Characterisation of vegetation response to climate change: a review. Sustainability 13:7265. doi: 10.3390/su13137265

Albrecht, T. R., Crootof, A., and Scott, C. A. (2018). The water-energy-food Nexus: a sunliystematic review of methods for nexus assessment. Environ. Res. Lett. 13:043002. doi: 10.1088/1748-9326/aaa9c6

Al-Saidi, M. (2017). Conflicts and security in integrated water resources management. Environ. Sci. Policy 73, 38-44. doi: 10.1016/j.envsci.2017.03.015

Antonelli, M., and Tamea, S. (2015). Food-water security and virtual water trade in the Middle East and North Africa. Int. J. Water Resour. Dev. 31, 326-342. doi: 10.1080/07900627.2015.1030496 to see how they could help promote sustainable development. Themes or words dynamics in the water, energy, food nexus research field and the most emerging and frequent keywords used in the field were identified. For instance, the relevant words or frequently mentioned words in the water, energy, food nexus studies are water, food, decision making, sustainable development which were mentioned 11, 10, 9, and 7 times respectively in the author's key terms used in water, energy, food nexus studies These connote that all these prominent themes relevant in water, energy, food nexus studies. More so, the lack of a unique or specific database for water, energy, food nexus contributed to the gaps in implementing water, energy, food nexus. In summary, it is important to establish an integrated data and analysis toolbox that incorporates existing global datasets on the water, energy, food nexus. This data or toolbox will be used to model and analyze water, energy, food resources and their interconnections at a regional or country level, this will help in having food-secured societies.

\section{DATA AVAILABILITY STATEMENT}

The original contributions presented in the study are included in the article/supplementary material, further inquiries can be directed to the corresponding author/s.

\section{AUTHOR CONTRIBUTIONS}

The author confirms being the sole contributor of this work and has approved it for publication.

\section{ACKNOWLEDGMENTS}

The author would like to thanks Ololade O.O., for her scholarly advice on the paper.

Bakhshianlamouki, E., Masia, S., Karimi, P., van der Zaag, P., and Sušnik, J. (2020). A system dynamics model to quantify the impacts of restoration measures on the water-energy-food nexus in the Urmia lake Basin, Iran. Sci. Total Environ. 708:134874. doi: 10.1016/j.scitotenv.2019.134874

Barbarà Mir, L. (2020). The Water-Energy-Food Nexus to Tackle Climate Change in Morocco.

Bell, A., Matthews, N., and Zhang, W. (2016). Opportunities for improved promotion of ecosystem services in agriculture under the Water-EnergyFood Nexus. J. Environ. Stud. Sci. 6, 183-191. doi: 10.1007/s13412-0160366-9

Bizikova, L. (2019). Integrating the Water-Energy-Food Nexus Into Policy and Decision-Making: Opportunities and Challenges. Policy and Governance in the Water-Energy-Food Nexus. London: Routledge. doi: 10.4324/978042942 7718-3

Bizikova, L., Roy, D., Swanson, D., Venema, H. D., and McCandless, M. (2013). The Water-Energy-Food Security Nexus: Towards a Practical Planning and DecisionSupport Framework for Landscape Investment and Risk Management. Winnipeg: International Institute for Sustainable Development.

Boluwade, A. (2021). Impacts of climatic change and database information design on the water-energy-food nexus in water-scarce regions. Water Energy Nexus 4, 54-68. doi: 10.1016/j.wen.2021.03.002

Busayo, E. T., Kalumba, A. M., and Orimoloye, I. R. (2019). Spatial planning and climate change adaptation assessment: perspectives from Mdantsane Township dwellers in South Africa. Habit. Int. 90:101978. doi: 10.1016/j.habitatint.2019.04.005 
Cabello, V., Romero, D., Musicki, A., Pereira, Â. G., and Peñate, B. (2021). Co-creating narratives for WEF nexus governance: a quantitative storytelling case study in the Canary Islands. Sustain. Sci. 16, 1363-1374. doi: 10.1007/s11625-021-00933-y

Dyosi, M., Kalumba, A. M., Magagula, H. B., Zhou, L., and Orimoloye, I. R. (2021). Drought conditions appraisal using geoinformatics and multi-influencing factors. Environ. Monitor. Assess. 193, 1-19. doi: 10.1007/s10661-021-09126-7

El-Gafy, I. (2017). Water-food-energy nexus index: analysis of water-energyfood nexus of crop's production system applying the indicators approach. Appl. Water Sci. 7, 2857-2868. doi: 10.1007/s13201-017-0551-3

Endo, A., Tsurita, I., Burnett, K., and Orencio, P. M. (2017). A review of the current state of research on the water, energy, and food nexus. J. Hydrol. 11, 20-30. doi: 10.1016/j.ejrh.2015.11.010

European Commission (2019). Water - Energy nexus in Europe. Available online at: https://setis.ec.europa.eu/water-energy-nexus-europe_en\#details (accessed September 25, 2021).

FAO. (2014). The State of Food Insecurity in the World (SOFI). https://www.fao. org/3/i4030e/i4030e.pdf

Fedoroff, N. V., Battisti, D. S., Beachy, R. N., Cooper, P. J., Fischhoff, D. A., Hodges, C. N.., et al. (2010). Radically rethinking agriculture for the 21 st century. Science 327, 833-834. doi: 10.1126/science.1186834

Fernández-Ríos, A., Laso, J., Campos, C., Ruiz-Salmón, I., Hoehn, D., Cristóbal, J., et al. (2021). Towards a Water-Energy-Food (WEF) nexus index: a review of nutrient profile models as a fundamental pillar of food and nutrition security. Sci. Total Environ. 789:147936. doi: 10.1016/j.scitotenv.2021.147936

Hack, J. (2015). Application of payments for hydrological ecosystem services to solve problems of fit and interplay in integrated water resources management. Water Int. 40, 929-948. doi: 10.1080/02508060.2015.1096122

Hoff, H. (2011). "Understanding the Nexus," in Background Paper for the Bonn2011 Nexus Conference: The Water, Energy and Food Security Nexus (Stockholm).

Hoolohan, C., Larkin, A., McLachlan, C., Falconer, R., Soutar, I., Suckling, J., et al. (2018). Engaging stakeholders in research to address water?energy?food (WEF) nexus challenges. Sustainability Sci. 13, 1415-1426.

Hua, E., Wang, X., Engel, B. A., Qian, H., Sun, S., and Wang, Y. (2021). Water competition mechanism of food and energy industries in WEF Nexus: a case study in China. Agric. Water Manag. 254:106941. doi: 10.1016/j.agwat.2021.106941

Hülsmann, S., Sušnik, J., Rinke, K., Langan, S., van Wijk, D., Janssen, A. B., et al. (2019). Integrated modelling and management of water resources: the ecosystem perspective on the nexus approach. Curr. Opin. Environ. Sustain. 40, 14-20. doi: 10.1016/j.cosust.2019.07.003

King, C., and Jaafar, H. (2015). Rapid assessment of the water-energy-foodclimate nexus in six selected basins of North Africa and West Asia undergoing transitions and scarcity threats. Int. J. Water Resour. Dev. 31, 343-359. doi: 10.1080/07900627.2015.1026436

Lazaro, L. L. B., Giatti, L. L., and de Oliveira, J. A. P. (2021). Water-energy-food nexus approach at the core of businesses-How businesses in the bioenergy sector in Brazil are responding to integrated challenges? J. Cleaner Prod. 303:127102. doi: 10.1016/j.jclepro.2021.127102

Liu, H., Peng, K., Li, W., and Cao, Y. (2019). Investigation on the trends and characteristics of articles on submerged macrophytes: perception from bibliometrics between 1991 and 2018. J. Freshw. Ecol. 34, 703-713. doi: 10.1080/02705060.2019.1676319

Mabhaudhi, T., Simpson, G., Badenhorst, J., Mohammed, M., Motongera, T., Senzanje, A., et al. (2018). Assessing the State of the Water-Energy-Food (WEF) Nexus in South Africa. Pretoria: Water Research Commission (WRC).

Marchand, R. D., Koh, S. L., and Morris, J. C. (2015). Delivering energy efficiency and carbon reduction schemes in England: lessons from green deal pioneer places. Energy Policy 84, 96-106. doi: 10.1016/j.enpol.2015. 04.035

Markantonis, V., Reynaud, A., Karabulut, A., El Hajj, R., Altinbilek, D., Awad, I. M., et al. (2019). Can the implementation of the water-energy-food nexus support economic growth in the Mediterranean region? The current status and the way forward. Front. Environ. Sci. 7:84. doi: 10.3389/fenvs.2019.00084

Martinez, P., Blanco, M., and Castro-Campos, B. (2018). The water-energyfood nexus: a fuzzy-cognitive mapping approach to support nexus-compliant policies in Andalusia (Spain). Water 10:664. doi: 10.3390/w10050664
Mohtar, R. H., and Daher, B. (2012). Water, Energy, and Food: The Ultimate Nexus. Encyclopedia of Agricultural, Food, and Biological Engineering. Baco Raton, FL: CRC Press, Taylor and Francis Group.

Mpandeli, S., Naidoo, D., Mabhaudhi, T., Nhemachena, C., Nhamo, L., Liphadzi, S., et al. (2018). Climate change adaptation through the water-energyfood nexus in southern Africa. Int. J. Environ. Res. Public Health 15:2306. doi: 10.3390/ijerph15102306

Naidoo, D., Nhamo, L., Mpandeli, S., Sobratee, N., Senzanje, A., Liphadzi, S., et al. (2021). Operationalising the water-energy-food nexus through the theory of change. Renew. Sustain. Energy Rev. 149:111416. doi: 10.1016/j.rser.2021.111416

National Planning Commission. (2013). National Development Plan Vision 2030.

Nhamo, L., Mabhaudhi, T., Mpandeli, S., Dickens, C., Nhemachena, C., Senzanje, A., et al. (2020). An integrative analytical model for the water-energyfood nexus: South Africa case study. Environ. Sci. Policy 109, 15-24. doi: 10.1016/j.envsci.2020.04.010

Oludare, S. D., Victo, N., Margaret, S. K., Miracle Nevo, C., and Bwambale, J. (2020). COVID-19 and the water-energy-food nexus in Africa: evidence from Nigeria, Uganda, and Tanzania. World water Policy 6, 176-201. doi: 10.1002/wwp2.12039

Orimoloye, I. R., Belle, J. A., and Ololade, O. O. (2021a). Exploring the emerging evolution trends of disaster risk reduction research: a global scenario. Int. J. Environ. Sci. Technol. 18, 673-690. doi: 10.1007/s13762-020-0 2847-1

Orimoloye, I. R., Mazinyo, S. P., Kalumba, A. M., Ekundayo, O. Y., and Nel, W. (2019). Implications of climate variability and change on urban and human health: a review. Cities 91, 213-223. doi: 10.1016/j.cities.2019.01. 009

Orimoloye, I. R., Mazinyo, S. P., Nel, W., and Iortyom, E. T. (2018). Assessing changes in climate variability observation and simulation of temperature and relative humidity: a case of east london, South Africa. Res. J. Environ. Sci. 12, 1-13. doi: 10.3923/rjes.2018.1.13

Orimoloye, I. R., and Ololade, O. O. (2021). Global trends assessment of environmental health degradation studies from 1990 to 2018. Environ. Dev. Sustain. 23, 3251-3264. doi: 10.1007/s10668-020-00716-y

Orimoloye, I. R., Zhou, L., and Kalumba, A. M. (2021b). Drought disaster risk adaptation through ecosystem services-based solutions: way forward for South Africa. Sustainability 13:4132. doi: 10.3390/su13084132

Ozdogan, B., Gacar, A., and Aktas, H. (2017). Digital agriculture practices in the context of agriculture 4.0. J. Econ. Finance Account. 4, 186-193. doi: 10.17261/Pressacademia.2017.448

Proctor, K., Tabatabaie, S. M., and Murthy, G. S. (2021). Gateway to the perspectives of the food-energy-water nexus. Sci. Total Environ. 764:142852. doi: 10.1016/j.scitotenv.2020.142852

Pueppke, S. G. (2021). Ancient WEF: water-energy-food Nexus in the Distant Past. Water 13:925. doi: 10.3390/w13070925

Purwanto, A., Sušnik, J., Suryadi, F. X., and de Fraiture, C. (2021). Quantitative simulation of the water-energy-food (WEF) security nexus in a local planning context in Indonesia. Sustain. Prod. Consumption 25, 198-216. doi: 10.1016/j.spc.2020.08.009

Ringler, C., Bhaduri, A., and Lawford, R. (2013). The nexus across water, energy, land and food (WELF): potential for improved resource use efficiency? Curr. Opin. Environ. Sustain. 5, 617-624. doi: 10.1016/j.cosust.2013. 11.002

Rosales-Asensio, E., de la Puente-Gil, Á., García-Moya, F. J., Blanes-Peiró, J., and de Simón-Martín, M. (2020). Decision-making tools for sustainable planning and conceptual framework for the energy-water-food nexus. Energy Rep. 6, 4-15. doi: 10.1016/j.egyr.2020.08.020

Saidmamatov, O., Rudenko, I., Pfister, S., and Koziel, J. (2020). Water-energy-food nexus framework for promoting regional integration in Central Asia. Water 12:1896. doi: 10.3390/w12071896

Scott, C. A., Kurian, M., and Wescoat, J. L. (2015). "The water-energyfood nexus: Enhancing adaptive capacity to complex global challenges," in Governing the Nexus, eds M. Kurian, R. Ardakanian (Cham: Springer), 15-38. doi: 10.1007/978-3-319-05747-7 2

Tantoh, H. B., Leonard, L., and Simatele, M. D. (2020). Strengthening the scaffolds of community flexibility: policy and institutional response to the 
rural water supply and sustainability challenge. Afr. Geogr. Rev. 39, 208-223. doi: 10.1080/19376812.2019.1694045

Tantoh, H. B., McKay, T. T., Donkor, F. E., and Simatele, M. D. (2021). Gender roles, implications for water, land and food security in a changing climate: a systematic review. Front. Sustain. Food Syst. 5:259. doi: 10.3389/fsufs.2021.707835

Urbinatti, A. M., Dalla Fontana, M., Stirling, A., and Giatti, L. L. (2020). 'Opening up'the governance of water-energy-food nexus: towards a science-policy-society interface based on hybridity and humility. Sci. Total Environ. 744:140945. doi: 10.1016/j.scitotenv.2020.1 40945

Venghaus, S., and Hake, J. F. (2018). Nexus thinking in current EU policies?The interdependencies among food, energy and water resources. Envir. sci. Policy, 90, 183-192.

WEF (2011). Global Risks 2011 Six Edition: An Initiative of the Risk Response Network. Geneva: World Economic Forum.

Wichelns, D. (2017). The water-energy-food nexus: is the increasing attention warranted, from either a research or policy perspective? Environ. Sci. Policy 69, 113-123. doi: 10.1016/j.envsci.2016.12.018

Yillia, P. T. (2016). Water-Energy-Food Nexus: Framing the Opportunities, Challenges and Synergies for Implementing the SDGs. Österreichische Wasserund Abfallwirtschaft, 68, 86-98.
Zhang, C., Chen, X., Li, Y., Ding, W., and Fu, G. (2018). Water-energy-food nexus: Concepts, questions and methodologies. J. Cleaner Prod. 195, 625-639.

Zhao, X., Li, Y. P., Yang, H., Liu, W. F., Tillotson, M. R., Guan, D., et al. (2018). Measuring scarce water saving from interregional virtual water flows in China. Environ. Res. Lett. 13:054012. doi: 10.1088/1748-9326/aaba49

Conflict of Interest: The author declares that the research was conducted in the absence of any commercial or financial relationships that could be construed as a potential conflict of interest.

Publisher's Note: All claims expressed in this article are solely those of the authors and do not necessarily represent those of their affiliated organizations, or those of the publisher, the editors and the reviewers. Any product that may be evaluated in this article, or claim that may be made by its manufacturer, is not guaranteed or endorsed by the publisher.

Copyright (C) 2022 Orimoloye. This is an open-access article distributed under the terms of the Creative Commons Attribution License (CC BY). The use, distribution or reproduction in other forums is permitted, provided the original author(s) and the copyright owner(s) are credited and that the original publication in this journal is cited, in accordance with accepted academic practice. No use, distribution or reproduction is permitted which does not comply with these terms. 